Revista do CESP, Belo Horizonte, v.35, n.54, p. 21-42, 2015

\title{
O engenheiro das flores
}

\section{The engineer of the flowers}

Letícia Villela Lima da Costa

Universidade Federal do Rio de Janeiro (UFRJ)

lelimavillela@gmail.com

Resumo: Este artigo trata de alguns aspectos da obra de Ruy Cinatti, poeta que, dentro do vasto panorama da poesia portuguesa do século XX, destaca-se pela sua singularidade. Sua poesia, bem como seus estudos científicos, evidenciam a preocupação e o conhecimento do autor com relação às questões ecológicas e antropológicas. Com sua formação científica interdisciplinar, tinha uma grande capacidade de enxergar a relação do homem com o meio em que vive de forma ampla e abrangente. Estas ideias refletem-se nos poemas que dedicou a Timor. A visão interdisciplinar e sensível do mundo torna sua obra poética e científica especial e singular, fazendo de Ruy Cinatti personagem fundamental na literatura portuguesa.

Palavras-chave: Ruy Cinatti; Timor; Poesia portuguesa do século XX.

Abstract: This paper concerns some aspects of the work of Ruy Cinnati, a poet whose singularity makes him an outstanding figure in the rich panorama of twentieth-century Portuguese poetry. His poems, as well as his scientific studies, testify to the author's interest and knowledge of environmental and anthropological issues. Thanks to his interdisciplinary scientific training he was uniquely able to see man's relationship with the environment. These ideas are clearly present in the poems he dedicated to Timor. His interdisciplinary and sensitive worldview makes his poetic and scientific work rather special and unique, so that Ruy Cinatti has become a fundamental name in Portuguese literature.

Keywords: Ruy Cinatti; Timor; Portuguese poetry in the 20th century. 
Recebido em 21 de novembro de 2015

Aprovado em 27 de dezembro de 2015

\section{Introdução}

$\mathrm{Na}$ construção do discurso referente a Timor Leste, Ruy Cinatti figura como autor fundamental. Elabora discursos sobre Timor, calcados na necessidade de se pensar as questões identitárias.

Com seu caráter multifacetado, Cinatti apresenta uma visão bastante ampla dos timorenses e de seu território através de sua obra poética e também dos seus inúmeros estudos científicos sobre o local e seus habitantes. É, sem dúvida, um dos poucos poetas que articula ciência e poesia, inaugurando uma nova visão de Timor. Graças à sua formação interdisciplinar - era engenheiro agrônomo, silvicultor, antropólogo, além de poeta -, podemos perceber nos seus escritos e na sua poesia uma enorme preocupação com as questões que envolvem o timorense e seu habitat.

Durante os diversos períodos em que esteve no território timorense, escreveu inúmeros estudos científicos, além das poesias. A análise de alguns desses documentos complementa a leitura da obra poética do autor. Fazem parte, também, desse universo discursivo as muitas fotos tiradas por ele, bem como os registros em filme, e ambos são elementos fundamentais para a compreensão global do discurso cinattiano acerca de Timor.

Podemos pensar as estadias de Cinatti em Timor em três fases: a primeira de 1946 a 1949, como chefe de gabinete do governador Óscar Ruas;a segunda de 1951 a 1956, onde desempenhou a função de chefe da recém-criada Repartição de Agricultura e a terceira em anos em que ele esteve lá por diversos períodos - 1958; 1961 a 1963 e 1966 - não só como agrônomo, mas também como antropólogo. É justamente essa formação antropológica que faz com que o autor estabeleça essa relação de proximidade e cumplicidade com o timorense.

\section{Um nómada em escala de partida}

Ruy Cinatti era um homem do mundo, grande amante de viagens e aventuras. A viagem, o deslocamento e o encontro com o desconhecido sempre o fascinaram. Tem razão Fernando Pinto do Amaral ao afirmar, 
no prefácio ao livro de Cinatti, que "o sentido de dádiva e a vontade de comunicar talvez ajudem, não diria a explicar, mas pelo menos tentar compreender um pouco melhor a ânsia de nomadismo que desde sempre animou Ruy Cinatti e sua escrita", ${ }^{1}$ ou ainda quando diz que: "este constante impulso que leva o poeta a viajar a cada instante torna-o detentor de uma grande imaginação e fá-lo também idealizar certos locais cuja privilegiada beleza o seduz de um modo especial". ${ }^{2}$

O sentimento de inquietação característico em Ruy Cinatti é bem descrito em um apontamento manuscrito, mostrando o seu interesse pelas viagens:

Como é admirável viajar, não importa aonde, desde que o desconhecido nos espera! Amanhã hão-de surgir novas coisas, tudo que é feito de imponderáveis, novas paisagens, outras faces, outras nuvens que me hão-de distrair do sonho e do quotidiano inevitável. Depois, há-de chegar o tempo em que eu me sinta como agora, e seja apenas um ser isolado que distribui as suas recordações ao longo das bissectrizes, que em mim se encontram como se no centro do mundo. À tarde ou à noite, como hoje, encostado à amurada do navio ou passeando, solitário, sobre uma terra que por agora, só me é permitido imaginar. ${ }^{3}$

No início de 1946, não vendo perspectivas de carreira e bastante insatisfeito com a falta de reconhecimento no trabalho, Ruy Cinatti demitiu-se da companhia de aviação Pan American, onde desempenhava a função de meteorologista. A esta altura, o Ministro Marcello Caetano nomeou uma nova administração para Timor. O futuro Governador, o capitão Óscar Ruas, fez um convite para que fosse seu secretário e chefe de gabinete. O convite foi prontamente aceito, e Cinatti chegou finalmente a Timor no mês de julho de 1946.

Suas primeiras impressões sobre a ilha foram realmente impactantes, e o recém-chegado deslumbrou-se com as maravilhas do território. Em documento intitulado De Timor (1949) faz uma pequena descrição do território, onde já se pode notar seu conhecimento de botânica, num discurso um tanto quanto científico:

\footnotetext{
${ }^{1}$ AMARAL apud CINATTI. Obra poética, p. 20.

${ }^{2}$ AMARAL apud CINATTI. Obra poética, p. 20.

${ }^{3}$ CINATTI apud STILWELL. A condição humana em Ruy Cinatti, p. 32.
} 
Quem desce pela primeira vez aos trópicos fica impressionado pela riqueza e complexidade da vida vegetal. Os panoramas de vegetação exuberante, os volumes de verdura de onde sobressaem palmeiras, bambus, árvores altíssimas e outros tipos de plantas, desencorajam, por vezes, o recém-chegado ansioso por conhecer o mundo que organizara, no seu espírito, de acordo com meia dúzia de regras aplicáveis à vegetação dos climas temperados. Tudo é novo e estranho. ${ }^{4}$

O estranhamento e a novidade proporcionaram-lhe uma imensa sensação de felicidade e vontade de percorrer a ilha em viagens de reconhecimento, o que efetivamente fez juntamente com o Governador. Entregou-se com ardor ao reconhecimento do território.

Foi assim que reconheci a maior parte da ilha, através de viagens repetidas que só vincaram o que havia de normal a observar. De avião, de automóvel e a cavalo, estas excursões abrangeram toda a ilha, desde a ponta de Tutuala, no extremo leste, ao território de Ocussi, na parte oeste. ${ }^{5}$

Foi um Timor devastado e bastante destruído que Cinatti encontrou em 1946. A invasão japonesa causara danos irreparáveis e a reconstrução se fazia urgente, daí a importância de tais viagens de reconhecimento, que certamente figurariam como documentação fundamental para auxiliar Timor na sua recuperação. Faz uma declaração indignada sobre a invasão japonesa:

Não se podem imaginar os estragos causados pela fúria de destruição dos japoneses. São os edifícios e as florestas. Foram as manadas de cavalos e os rebanhos de búfalos. Até os veados. E o estado miserável da população [...] confirma o martírio e a fome a que a ilha esteve sujeita desde $1942 .{ }^{6}$

A partir destas viagens Ruy Cinatti pretendia, como agrônomo e silvicultor, fazer uma minuciosa identificação da flora timorense. Além disso, buscava também, já com interesses antropológicos, iniciar um

\footnotetext{
${ }^{4}$ CINATTI apud STILWELL. A condição humana em Ruy Cinatti, p. 173.

${ }^{5}$ CINATTI. Explorações botânicas em Timor, p. 47.

${ }^{6}$ CINATTI. Explorações botânicas em Timor, p. 175.
} 
"estudo metódico e interdisciplinar do território, a fim de detectar as potencialidades materiais e humanas existentes" "para que, a partir daí, fosse possível realizar o desenvolvimento equilibrado da ilha, o que já mostra sua visão integradora e pioneira, especialmente no que tange ao desenvolvimento autossustentável.

Em uma carta ao Governador, datada de dezembro de 1946, demonstra seu empenho em entregar-se a um estudo aprimorado do território, quando escreve que: "O meu entusiasmo pela ilha continua a ser o mesmo ou melhor, acrescido pelo conhecimento vivo da realidade. [...] a verdade é que estou preso a esta ilha e entusiasma-me o que se está fazendo e o que se deve vir a fazer". ${ }^{8}$

A leitura de A ilha verde e vermelha de Timor, de Alberto Osório de Castro foi crucial para que ele desenvolvesse uma reflexão científica acerca da colonização:

O livro de Osório de Castro, além de ser exemplar único da história literária e de se assemelhar por estes e outros motivos à obra de Fernão Mendes Pinto, há-de ficar na literatura da especialidade como sendo a primeira contribuição moderna da fitografia timorense... O amadorismo científico e a falta de elementos informativos, longe de prejudicar a estrutura da obra, estimulou todas as faculdades da inteligência do autor, obrigando-o a aplicar a um mundo ignoto as várias facetas do seu poderoso talento descritivo. Qualquer coisa que se lhe depare é descrita com aquela frescura e novidade de quem inventa palavras certas para um conjunto de imagens que se experimentam pela primeira vez, sendo para considerar, sob um aspecto filosófico e político, que em 1909 tenha sido escrita por um poeta a seguinte afirmação: "Hoje a obra de colonização ou é científica ou não é nada." "9

Entretanto, Cinatti viu seus planos ruírem, pois Óscar Ruas o queria apenas para as funções de secretário de gabinete, confinando-o e limitando-o aos trabalhos burocráticos; mas, mesmo impedido de continuar suas atividades de investigação, aproveitou o tempo livre para

\footnotetext{
${ }^{7}$ STILWELL. A condição humana em Ruy Cinatti, p. 176.

${ }^{8}$ CINATTI apud STILWELL. A condição humana em Ruy Cinatti, p. 176.

${ }^{9}$ CINATTI. Obra poética, p.560.
} 
coletar exemplares de plantas e bichos da região. O resultado mais efetivo de tais andanças se faz sentir no estreitamento das suas relações com o povo timorense. Em uma entrevista dada em 1972, declara: "Comecei a perceber que os timorenses eram algo mais do que simples figuras exóticas numa paisagem já de si exótica." ${ }^{10}$

Começou, então, a enxergar o timorense não como uma figura destacada, mas como um semelhante, e passou a ter uma grande preocupação em conhecer e, principalmente, respeitar sua cultura. A partir de então, os laços de amizade intensificaram-se e Cinatti chegou mesmo a fazer um pacto de sangue com dois liurais timorenses, D. Armando Barreto, liurai de Aissa e D. Adelino Ximénes, liurai de Loré, permitindo-lhe isto acesso a segredos, como a existência de pinturas rupestres ocultas.

Nota-se, então, que sua preocupação não se restringia apenas às condições econômicas e ao aproveitamento racional dos recursos materiais da ilha. A situação do povo timorense figurava como peça fundamental neste complexo jogo. Para ele, o timorense é a essência da ilha, e é extremamente necessário e fundamental conhecê-lo e, especialmente, respeitá-lo. O mais importante nesse estreitamento de relações com os timorenses é, sem dúvida, o fato de ele ter sido aceito pelos habitantes da ilha como um irmão.

Através das viagens de reconhecimento pelo território timorense, estreita cada vez mais seus laços de amizade com o povo da ilha e acaba por ganhar a sua simpatia. Na entrevista dada em 1972, declara que os timorenses: "baptizaram-me de 'engenheiro das flores' e de 'senhor da chuva' - isto porque me viam colher plantas com flores e tantas vezes se ter dado o caso de chover quando, chegado a qualquer sítio, era sentida a falta de água nos campos cultivados."11

Em um esboço de carta de 1946, recolhido de seu espólio por Peter Stilwell, Cinatti afirma: "Estar nas colónias transforma as pessoas e eu sinto-me de certo modo uma pessoa diferente. Timor prendeu-me com cadeias de ferro, a ponto de estar disposto a iludir o bom senso ou o que ele me indica." 12

\footnotetext{
${ }^{10}$ CINATTI. Obra poética, p. 186.

${ }^{11}$ CINATTI apud STILWELL. A condição humana em Ruy Cinatti, p. 188.

${ }^{12}$ CINATTI apud STILWELL. A condição humana em Ruy Cinatti, p. 188.
} 
A paisagem o encanta e através dela há uma busca da compreensão da relação do Homem com o meio em que vive, já que esta é o elemento que liga o Homem e a Natureza. Para ele, a paisagem está além do que se vê, é algo que se sente, que se vive. É resultado de um processo bem mais complexo, e, assim como o homem, não é imutável. Ao contrário, está em constante mutação. Seguindo a perspectiva clássica, os geógrafos percebem a paisagem como a expressão materializada das relações do homem com a natureza, portanto não se pode dissociá-la do homem. Para Cinatti, a paisagem o liga a Timor. É o elemento primordial de ligação entre ele e o território timorense. No entanto, não é algo que se dá somente na visão, mas sim na alma. Em Páginas de um Diário Poético, o poeta traduz esse sentimento da seguinte forma:

Vivo as paisagens ao sabor dos afectos da alma. Sintoas, mais ou menos, como sinto a sede, a fome ou outro qualquer desequilíbrio fisiológico, com a diferença de que a alma não tem limites nem tempo para se saciar. É como se a elas me prendesse - filhas da mesma mãe igual cordão de placenta, e o sangue vibrasse unânime às diversas reações que as perspectivas, formas e coloridos possam despertar. Daí o sentir-me igual, quer me encontre num deserto frente ao magnificente mistério dos astros, quer como elemento contemplativo no organismo vivo da floresta tropical. (...) A paisagem é um estado de alma, ou de consciência, como lhe chamou Amiel; como tal, susceptível e aderente a variações infinitas. (...). De um ambiemte aliciante, rico de promessas e de factos, belo como a alma do homem!... Timor. Segunda pátria minha. ${ }^{13}$

\section{O poder simbólico da palavra}

No livro $O$ despertar da águia, Leonardo Boff ressalta que a origem filológica do termo sim-bólico provém do grego clássico e significa literalmente lançar (bállein) junto (syn), ou seja, "lançar as coisas de tal forma que elas permaneçam juntas". ${ }^{14}$ Nesse sentido, enxergar nas coisas seu valor simbólico significa reunir as realidades, convergindo

\footnotetext{
${ }^{13}$ CINATTI. Páginas de um diário poético, p. 2.

${ }^{14}$ BOFF. O despertar da águia, p. 11.
} 
as diversas forças num único feixe. A partir de tal concepção, pode-se compreender a relação de Ruy Cinatti com a natureza, os seres humanos e o mundo, já que ele procurava ver na natureza o seu valor simbólico e não apenas sua função utilitária e de manipulação.

Fernando Amaral afirma que "uma das principais traves-mestras da poesia de Cinatti consistiu numa associação entre a alma e a natureza, que mutuamente se correspondem e interpenetram." 15 Dessa forma, pode-se seguir o pensamento de Leonardo Boff, que ressalta que: "um ajuda reciprocamente o outro a existir e a se desenvolver. Todos se complementam e crescem juntos: as espécies, os ecossistemas e o inteiro universo." ${ }^{\prime 16}$ Percebe-se aí uma busca de equilíbrio entre o ser humano e a natureza, que norteia o pensamento ecológico e humano de Cinatti.

As denúncias que faz contra aqueles que erradamente, contrariando a orientação bíblica, agridem a natureza atentam para a arrogância dos homens em relação à terra. Em um de seus inúmeros escritos, Ruy Cinatti chega a ressaltar que: "Com o seu poder creador o homem modifica a Terra, dá-lhe novos caracteres e desenvolve condições que pela sua particularização quase se individualizam do meio". ${ }^{17}$ Neste sentido, o homem deveria usufruir daquilo que o meio ambiente tem, não de maneira indiscriminada, porém consciente e racional, para que a terra possa continuar a oferecer ao ser humano seus recursos naturais.

É interessante perceber que esta declaração faz coro com o que afirma Luís Carrisso (professor de botânica da Faculdade de Ciências da Universidade de Coimbra, que realizou inúmeros estudos da flora colonial em Angola, e fazia parte do conselho do Império), cujos escritos foram lidos por Cinatti. Na conferência "O conhecimento da flora e o progresso da agricultura colonial”, de 1936, lê-se:

(...) o homem civilizado dispõe de um formidável poder de destruição, ao qual, em breve, não escapará nenhum recanto do nosso Globo, e é urgente, nos limites do possível, evitar essa destruição insensata, que fará desaparecer prematuramente, e para sempre, o mais

${ }^{15}$ CINATTI. Obra poética, p. 20.

${ }^{16}$ BOFF. A águia e a galinha, p. 133.

${ }^{17}$ CINATTI. Impressões de uma viagem pelos territórios portugueses da África Ocidental, p. 5. 
precioso de todos os documentários, aquele que a Natureza intacta nos oferece, o quadro maravilhoso da criação. ${ }^{18}$

É a partir de tais ideias que se pode começar a compreender melhor a visão que Ruy Cinatti tem da ecologia, (ciência que, a essa altura, dá seus primeiros passos), da botânica e do papel do botânico, ${ }^{19}$ que compreende aspectos muito mais complexos do que simplesmente identificar a flora de determinados locais. Cinatti compreende essa profissão como um indicador do meio no qual os seres vivos atuam e se inter-relacionam. Isto quer dizer que se deve conhecer o meio ambiente em que os seres vivem para que a preservação da natureza se faça de maneira eficaz.

O trabalho do botânico não pretende apenas alcançar, com objectivos de ciência pura o conhecimento das formas vegetais e das suas associações. Visa ainda outros objectivos: a investigação das condições do meio físico e biológico, do quadro em que a actividade humana se há de desenvolver (...). Como o cartógrafo, o climatologista, o geólogo, o zoólogo e o etnógrafo, o botânico é, mais do que qualquer deles, o dianteiro que abre o caminho à ocupação económica racionalmente conduzida. ${ }^{20}$

Surge, nesse momento, um ponto de discussão e reflexão fundamental em relação ao meio ambiente, que é o importante caráter econômico que envolve a preservação da natureza, uma vez que é

(...) necessário proteger a Natureza, conservando alguns documentos que ela nos faculta, que, pela sua fidelidade, constituem a melhor base para a utilização científica das partes da Terra que ainda não foram abrangidas pela nossa civilização intensiva. A proteção da Natureza justifica-se assim, por motivos de ordem económica: corresponde a conservar um documentário do que a Terra é, para daí podermos inferir do que ela poderá ser. ${ }^{21}$

\footnotetext{
${ }^{18}$ CARRISSO apud CAETANO. Antologia colonial portuguesa, p. 233.

${ }^{19}$ É importante entender que aqui o botânico é encarado como um participante ativo na preservação da natureza.

${ }^{20}$ CARRISSO apud CAETANO. Antologia colonial portuguesa, p. 217-218.

${ }^{21}$ CARRISSO apud CAETANO. Antologia colonial portuguesa, p. 223.
} 
Pode-se dizer que Ruy Cinatti, como cientista, concordava com a visão apontada por Carrisso, a qual defende que somente uma utilização consciente da natureza garante que ela permaneça equilibrada, e só assim os seres humanos podem continuar a usufruir do que ela tem a oferecer, garantindo a sua própria sobrevivência, já que se deve buscar um equilíbrio entre os três reinos da natureza.

É fundamental ressaltar que Cinatti desenvolve inúmeros estudos sobre Timor, resultado das diversas viagens de reconhecimento que o autor fez pelo território ao longo dos anos em que lá esteve. Estes estudos tratam principalmente da flora timorense, sem, no entanto, ignorar a preocupação com um estudo do homem, já que esses se complementam. O próprio Cinatti afirma que "A natureza existe estreitamente ligada ao homem, dominando-o e deixando-se constantemente dominar". ${ }^{22}$

Tais percepções refletem-se de forma bastante significativa na sua obra poética. Com poemas carregados de lirismo, o poeta busca as ligações essenciais com a natureza, pelo poder da poesia, refazendo esta aliança. Ela seria, então, o elo de ligação entre o Homem e a Natureza. Dentro desse pensamento, pode-se afirmar que a poesia cinattiana figura como a expressão clara dessa convergência, dessa aliança. Tal comunhão se dá no mundo das palavras, mais precisamente na poesia. O poder da palavra aparece em todo seu esplendor, pois, segundo Ruy Cinatti: "A palavra representa não apenas o instrumento graças ao qual nos expressamos, mas o instrumento de investigação, de invenção, por assim dizer, a chave da porta do mundo inteligível."${ }^{23}$

Essas concepções refletem-se no fazer poético de Ruy Cinatti, especialmente em alguns poemas dedicados a Timor, muitos dos quais imbuídos de uma percepção que se pode chamar de "ecológica", uma vez que fica clara, em seus versos, a preocupação em abordar temas relativos à ecologia, numa simbiose entre ciência e poesia.

O poema "Parâmetro Ecológico" é um bom exemplo de como se dá essa convivência da ciência com a arte poética. Dividido em três partes, na primeira, o poeta alude ao mito de Sísifo, ${ }^{24}$ que representa a

${ }^{22}$ CINATTI. Impressões de uma viagem pelos territórios portugueses da África Ocidental, p. 6.

${ }^{23}$ CINATTI apud STILWELL. A condição humana em Ruy Cinatti, p. 45.

${ }^{24}$ Sísifo foi condenado, por ter espalhado levianamente seus segredos, pelos deuses do Olimpo, a rolar um enorme rochedo, incessantemente, até o alto de uma montanha. 
terrível consciência da condenação a um trabalho inútil e sem esperança. Há um pouco de Sísifo em Cinatti neste sentido, uma vez que ele se sente aprisionado pelas tarefas burocráticas, que o impedem de realizar seu trabalho da maneira como gostaria. Por outro lado, a aguda consciência de Sísifo representa também a persistência, a única coisa que pode salvar um ideal mais humanista. Esta consciência, ou seja, a não-desistência, é a salvação, que deve estar dentro do espírito de cada um, fazer parte da essência de cada um. Essa salvação intima o ar que respiramos, que é o elemento de união da humanidade.

Parâmetro Ecológico

1

Aguda consciência de Sísifo,
que é no espírito
salvação humana,
intima-me o ar puro que respiro,
atende, atenta,
aviso ímpar,
o fecundo enlace:
Natureza-Tempo,
o devir no Espaço..$^{25}$

$\mathrm{Na}$ segunda parte, o poeta fala da devastação causada pelos colonizadores e pelas consecutivas invasões do território timorense. Condena a tentativa intencional de desfiguração do território, alertando para a cegueira da maioria dos governantes, que preferem não ver o que acontece. Faz de um pinheiro, o podocarpus, o símbolo da destruição causada pela mão do homem. Declara que este pinheiro está solitário devido à devastação (devemos levar em conta que nunca há um pinheiro sozinho). Esta árvore será o testemunho, para aqueles que por ali passarem, da ação predatória dos que destroem a natureza, transformando-a em um deserto.

\footnotetext{
Quando, finalmente, ele conseguia chegar ao cimo da montanha, a pedra caía novamente. O castigo imposto a Sísifo simboliza o sofrimento de ter a consciência da condenação a um trabalho inútil.

${ }^{25}$ CINATTI. Obra poética, p. 520.
} 
É notório ressaltar que Cinatti, neste poema, já aponta para um problema que preocupa a humanidade nos dias de hoje: o processo de desertificação da Terra, que se acelera cada vez mais, devido aos constantes desmatamentos.

Onde passei havia florestas

há tantos anos...

Hoje, a paisagem é um deserto

de caules nus.

Ninguém me distende o esclarecer

de tal desengano.

Havia florestas, um crescer

sobrehumano.

Pedras e troncos isolados, assistem sós.

$\mathrm{O}$ capim cresce. Ah, conhecer

o que assim foi, de sempre, com o tédio

- fruto visível de um sentir abstracto!

Ninguém, ou só poucos, ousam ver

a fundo, o facto.

Uma árvore só: um Podocarpus, raro "pinheiro" de sensíveis cumes, acusa a mão do homem, denuncia, à vista de Maubisse, subindo a estrada para a Cumiada, o que ali havia...

Sinto vegetação nascer ao meu lado como já foi na realidade destas encostas - hoje pedraria e cheiro a hortelã!...

Um Podocarpus, vestígio de arvoredo outrora extenso e imponente, solitário hoje.

Tamanha ausência supõe anos de fogo arrepiando montes circundantes. 


\author{
Um Podocarpus, \\ sacralizado pelos Timorenses... \\ é testemunho \\ para os viajantes. ${ }^{26}$
}

Na nota aproximativa a "Parâmetro Ecológico", Ruy Cinatti faz uma descrição científica bastante minuciosa da árvore citada:

A podocárpea mencionada corresponde à espécie Podocarpus imbricata B1., Ai-Amal, em tetum. Encontrei-a pela primeira vez em 1947 nas vertentes do monte Boicau, sebre-elevado a $2100 \mathrm{~m}$, na cordilheira de Matebian, e, pouco mais tarde, no Mundo Perdido, a $1500 \mathrm{~m}$. É dominante na floresta de chuva de montanha, constituída por razoável acervo de fanerogâmicas (dicotilédones, principalmente) e de criptogâmicas (fetos arbóreos, licopódios, musgos, líquenes e fungos), mas aparece, por vezes, sob forma gregária, em povoamentos quase puros (...). É uma árvore grande (alguns exemplares atingem 40m de altura), de madeira leve, branco-acastanhada, pouco resistente aos incêndios, embora subsista, por motivos que desconheço, em locais onde as outras espécies das subassociações desapareceram, como é o caso de Maubisse, mencionado no poema, e ali reduzida a dois exemplares decrépitos em 1958, talvez por ambos estarem protegidos por plataforma empedrada, como soe acontecer com as árvores sacralizadas pelos Timorenses. ${ }^{27}$

Pode-se notar o profundo conhecimento do autor com relação à vegetação do território timorense. Em todos os poemas, o poeta faz questão de mostrar sua indignação contra as atitudes tomadas pela administração colonial com relação ao manejo da natureza. Ressalta que os governantes se utilizam dos recursos naturais, e transformam a natureza sem que haja uma preocupação em equilibrá-la e muito menos preservá-la. Para ilustrar melhor este pensamento, é interessante destacar uma passagem do estudo científico que Cinatti elaborou e publicou em 1950, intitulado Esboço histórico do sândalo no Timor português, onde o autor ressalta que a exploração dessa árvore cresceu em ritmo acelerado

${ }^{26}$ CINATTI. Obra poética, p. 251.

${ }^{27}$ CINATTI. Obra poética, p. 553. 
no século XX. A passagem que segue abaixo confirma a ignorância científica/botânica dos administradores, que sequer se davam ao trabalho de conhecer as condições de cultivo do sândalo.

é que os administradores, no empenho em levar a cabo a empresa, limpavam a terra de quaisquer ervas estranhas e chegavam a extremos de cuidados tais que semeavam o sândalo em canudos de bambu! [...] Tudo isto porque se desconhecia, após 300 anos de exploração intensa, o parasitismo do sândalo! ${ }^{28}$

Por fim, na terceira parte, o poeta acredita que sua poesia é a prova da cegueira dos homens que governam Timor, que, numa tentativa de justificar o que não pode ser justificado dizem que foi sempre assim. Mas a natureza sabe que foi devastada, destruída pela ganância dos governantes.

Meu gesto lento de fotografia

atesta cegueira aos governantes, que olhando o que não vêem ousam dizer:

Foi sempre assim!

A Natureza, que é manjar dos vivos, responde por mim.

Onde havia florestas há só capim

e fome que aos vivos arrebata! ${ }^{29}$

No "gesto lento de fotografia", que os seus poemas evocam, Cinatti atenta para a preservação da natureza, ressaltando a beleza de seus elementos naturais. Defende uma política de aproveitamento racional dos recursos naturais, condenando a administração colonial, que parece não se preocupar com isso. E declara que:

os factos, os administrativos incluídos, confirmam-nas com maior eloqüência nos efeitos desastrosos de uma política de exploração, a nível de depredadora, sem que tenha

${ }^{28}$ CINATTI. Esboço histórico do sândalo no Timor português, p. 6.

${ }^{29}$ CINATTI. Obra poética, p. 521. 
havido, a menos de efémeras insignificativas tentativas, a correspondente política de conservação e manutenção. ${ }^{30}$

É interessante e extremamente belo o destaque que o poeta dá à importância da árvore: "A verdade é que ainda não me cansei de proclamar publicamente que em Timor A ÁRVORE É GARANTIA DO PÃO." 31

Partindo-se de tais declarações, pode-se reafirmar, como já foi dito anteriormente, que a ocupação desordenada e a utilização irracional do meio ambiente é uma das suas principais preocupações. Ele mesmo afirma que

(...) Timor iria ardendo, as árvores derrubando-se, a baía de Díli assoreando-se, as estradas escorregando, o solo lavando-se e calcinando-se, as fontes secando... em obediência a um processo administrativo certinho como um silogismo em que as premissas estão inteiramente falseadas. E quando teria sido tudo tão mais fácil, de início, se tivessem protegido as cumiadas ou outros locais estratégicos onde a erosão ataca, indomável: ou se tivesse lançado mão da sabedoria timorense, escalonando as vertentes abruptas em terraços empedrados, como em Marobo e Báguia; ou da própria crença dos timorenses gentios, que consideram sagradas e, portanto, intocáveis, as florestas de altitude... ${ }^{32}$

Segundo a crença timorense, as florestas são sagradas, e, por isso, não deveriam ser tocadas e/ou modificadas pelo homem. Em outras palavras, o homem não tem o direito de mexer no que é sagrado.

\section{Poeta por dom natural}

No prefácio de Um cancioneiro para Timor, Jorge Dias afirma que "Cinatti é poeta por dom natural. Nasceu para sentir e para comunicar em poesia a beleza e o sentido oculto que vê nas coisas e na vida". ${ }^{33} \mathrm{Na}$ sua

\footnotetext{
${ }^{30}$ CINATTI. Obra poética, p. 552.

${ }^{31}$ CINATTI. Obra poética, p. 551.

${ }^{32}$ CINATTI. Obra poética, p. 521.

${ }^{33}$ DIAS apud CINATTI. Um cancioneiro para Timor, p. 6.
} 
singular combinação de cientista e poeta, capta como poucos o sentido real das coisas, já que: "Procura dar à sua poesia, quer no aspecto formal, quer no espírito, o máximo de identificação com o mundo real em que viveu e amou, mas interpreta esse mundo em termos exatos de cientista." ${ }^{34}$

Os elementos naturais exaltados em sua poesia não aparecem apenas para ilustrar seus poemas; mais do que isso, fazem parte do universo poético cinattiano de uma forma particular. Cada um deles tem um significado único, especial, como afirma Jorge Dias:

O espírito do poeta formado na disciplina das ciências naturais, permitiu-lhe chamar as coisas pelo seu nome. Não caiu nas abstrações pobres e banais comuns à maioria dos poetas líricos, que só sabem falar de pássaros, de árvores, sem saberem que todas as árvores, flores e bichos têm os seus nomes próprios, a sua vida própria e o seu significado próprio. ${ }^{35}$

O próprio Cinatti afirma que "A poesia é a autobiografia do poeta ou do nómada em escala de partida: o seu cântico". ${ }^{36}$ Efetivamente, esse nomadismo é uma característica marcante na vida e na obra de Ruy Cinatti. O poeta é um "nómada em escala de partida", ou seja, está sempre à espera de uma nova viagem, de uma nova partida, mesmo que seja para dentro de si mesmo.

A poesia é o cântico, o hino dessa nova partida. Baseando-se em tais ideias, deve-se levar em conta as palavras de Maria João Borges: "Ler a obra poética de Ruy Cinatti implica interrogarmo-nos, antes de tudo o mais, acerca da personalidade que nela se retrata, fazendo dos versos o roteiro da sua peregrinatio". ${ }^{37}$ Ainda de acordo com Maria João Borges: "A poesia tem a sua raiz numa experiência interior, de ordem metafísica. A orientação religiosa da personalidade determina o registo poético, que espelha, assim, o que é da esfera do biográfico."38

Somada a essa preocupação com as questões que envolvem o ser humano, a obra poética cinattiana é também impregnada por sua concepção cristã de mundo, que prega a igualdade e a fraternidade

\footnotetext{
${ }^{34}$ DIAS apud CINATTI. Um cancioneiro para Timor, p. 7.

${ }^{35}$ DIAS apud CINATTI. Um cancioneiro para Timor, p. 6.

${ }^{36}$ CINATTI apud STILWELL. A condição humana em Ruy Cinatti, p. 333.

${ }^{37}$ BORGES. Cinatti: a poesia como investidura, p. 130.

${ }^{38}$ BORGES. Cinatti: a poesia como investidura, p. 130.
} 
entre os homens, seguindo os desígnios de São Francisco de Assis e o ensinamento bíblico "Amai-vos uns aos outros e ao próximo como a ti mesmo". Pode-se então dizer que, em Ruy Cinatti, "vida e obra afinam por um diapasão religioso", ${ }^{39}$ ou seja, a religião e o entendimento cristão do mundo não são apenas a base, mas também elementos essenciais para a sua compreensão do universo. Essa maneira de compreender o universo consiste na inter-relação e na integração dos seres. A natureza e o universo dependem dessa interseção. Nas palavras de Leonardo Boff:

A natureza e o universo não constituem simplesmente o conjunto dos objetos existentes como pensava a ciência moderna. Constituem, sim, uma teia de relações, em constante interação, como os vê a ciência contemporânea. Os seres que interagem deixam de ser apenas objetos. Eles se fazem sujeitos, sempre relacionados e interconectados, formando um complexo sistema de inter-retro-relações. O universo é, pois, o conjunto das relações dos sujeitos. ${ }^{40}$

Seu engajamento nas questões sociais, bem como a sua crítica à dominação colonial pode ser ilustrada também pela questão da lipa, que é um pano tradicional usado em volta da cintura pelos timorenses do sexo masculino. O governo de Díli havia decretado a proibição do uso deste pano no ano de 1954. Ruy Cinatti faz então um protesto condenando tal medida e envia-o para Lisboa. No documento, a indignação do autor com relação à prepotência e à arbitrariedade desta medida está bastante clara. Justifica o uso da lipa, ressaltando seu caráter prático e artístico. $\mathrm{O}$ autor parte em defesa da manutenção e, principalmente, do respeito pela cultura do timorense. Segundo sua opinião, esta proibição:

[...] denota a prepotência deste Governo, o completo desrespeito pela dignidade de atingidos e não atingidos, e uma imprevidência política que, em conjunto com outras do mesmo género, pode vir a ter conseqüências perigosas para a nossa soberania, (...). Sob pretexto de que a lipa era imprópria do sexo, deu-se foros de lei a uma arbitrariedade que, em última análise, evidencia total ignorância das condições locais e da cultura dos povos (...). Esqueceram-

${ }^{39}$ BORGES. Cinatti: a poesia como investidura, p. 68.

${ }^{40}$ BOFF. A águia e a galinha, p. 74. 
se, no entanto, que o timor usa calção debaixo da lipa e que esta serve, não apenas para adorno que a tradição legitimou, mas sobretudo para os fins práticos de proteger o corpo contra o sol, contra a chuva, contra os frios da noite ou da montanha, contra os mosquitos, e até contra os espinhos do mato. ${ }^{41}$

Timor é, para Cinatti, um espaço de conhecimento e aprendizado de si mesmo e dos outros, e a sua poesia pode ser encarada como o testemunho dessa nova experiência. Isto faz com que esta ilha, tão longe de Portugal, assuma um lugar especial para o autor. Para Jorge de Sena, o Timor de Ruy Cinatti: "Não é, porém, nele, uma paisagem literária, ou um daqueles mundos a que os poetas se agarram para criar-se uma pequena mitologia própria; é mais: um objecto em que se concretiza a aproximação do poeta consigo mesmo e com a vida humana dos outros." ${ }^{42}$

Ruy Cinatti tinha um sentimento de compaixão para com Timor e os timorenses. Compaixão, entretanto, não no sentido de ter pena, mas no seu sentido original, de compartilhar o que o outro sente e pensa. De fato, ele compartilhava os sentimentos dos timorenses e esta compaixão, e todo o seu comprometimento com as questões que envolviam a ilha e seus habitantes, fez dele um homem especial aos olhos dos nativos, tão especial que foi aceito como um irmão. O pacto de sangue que fez com dois chefes timorenses é o ritual que celebra essa aceitação. Os dois homens, ao celebrarem o pacto, transformam-se num só. O ritual une-os, tornando-os aliados. O sol e a lua, elementos carregados de simbolismo, são as testemunhas desta união.

Em Paisagens timorenses com vultos, Ruy Cinatti descreve mais detalhadamente este ritual, onde se percebe a importância dos elementos naturais como fonte da energia que irá unir os dois homens:

Corta-se um dedo, mete-se dentro de um copo com tuasabo, aguardente de palmeira, e depois bebe-se. Há um sacerdote gentio que diz "Maromakfeto !Maromak mane!", que quer dizer: "a energia que atravessa o sol fêmea, a energia que atravessa o sol macho". A seguir, tal como sucede na consagração a um bispo, as mãos unidas e um lenço enrolado à volta delas, canta-se um poema: nós

\footnotetext{
${ }^{41}$ CINATTI apud STILWELL. A condição humana em Ruy Cinatti, p. 220.

${ }^{42}$ SENA apud CINATTI. Obra poética, p. 485.
} 
dois somos amigos, se vencermos somos iguais, se formos derrotados somos iguais, tu bebeste a água da ribeira dela, eu também bebi a água da ribeira dela. ${ }^{43}$

Ao ser aceito pelos timorenses como um irmão, um aliado, Ruy Cinatti transcende o papel de cientista/explorador/colonizador e passa, por juramento de sangue e, portanto de fidelidade, a fazer parte daquela comunidade, daquele povo. Assumindo Timor como nova pátria, tornase português e timorense. A identidade timorense tem, entretanto, um significado particular, pois é escolhida pelo espírito e pelo coração. Sophia Andresen ressalta o significado desse ritual de união e consequente aceitação:

Ao longo dos dias, ao longo dos anos, muitas vezes falei de Timor com o Ruy. Contou-me como celebrara o pacto de sangue com o chefe de uma família timorense e como por isso, segundo a lei ancestral de Timor, se tornara ele próprio um timorense. De facto para ele Timor era uma verdadeira pátria. Para mim era uma ilha encantada no Extremo Oriente, mas para ele uma pátria - o lugar onde encontrara o seu destino. ${ }^{44}$

Em uma carta a um professor seu de Oxford escreve:

Estou muito feliz em Timor. (...). Esta ilha é um paraíso antropológico, completamente ignorado e demasiado vasto para um homem só (...). Encontrei três lugares com pinturas rupestres, qualquer dos três no extremo leste da ilha, distrito de Lautem, posto administrativo de Tutuala (...). Tudo somado estou muito feliz e não voltarei à Europa dentro dos próximos seis meses. Os Timorenses são meus amigos e um deles disse que eu era como Deus. ("Sr. Eng. à nès a Maromák" $)^{45}$

${ }^{43}$ CINATTI apud STILWELL. A condição humana em Ruy Cinatti, p. 302.

${ }^{44}$ Excerto do prefácio a $\dot{A}$ janela de Timor. Disponível em: <www.ruialme.pt $>$.

${ }^{45}$ CINATTI apud STILWELL. A condição humana em Ruy Cinatti, p. 302. 


\section{Considerações conclusivas}

Pode-se encarar como interdisciplinar uma visão que integra os diversos saberes, sendo, portanto, aquela onde há inúmeras interseções entre os diversos aspectos observáveis no universo. Ruy Cinatti, com sua ampla formação intelectual, apresentava esta visão interdisciplinar que se refletia constantemente na sua maneira de encarar o mundo. A interligação de ideias é a base, não só dos seus textos científicos, mas também de sua poesia. O estudo mais aprofundado de sua obra torna-se fundamental, já que essa concepção integradora, resultado dessa visão, serve para que haja uma melhor compreensão de quem somos e do mundo em que vivemos.

Seus estudos científicos e os poemas dedicados a Timor figuram como uma importante e fundamental fonte de conhecimento acerca do local. Através de seus escritos, o autor traz à tona questões essenciais do ser humano, revelando e, sobretudo, divulgando esta ilha, até hoje pouco conhecida.

Ruy Cinatti era, de fato, um homem à frente de seu tempo. Com alma inquieta, sua cabeça borbulhava de ideias inovadoras, que se refletem nos seus poemas, cartas e textos científicos. Foi pioneiro ao abordar questões ligadas ao aspecto ecológico e ao manejo consciente da terra, o que se confirma tanto pelos seus estudos científicos como por suas poesias. Com sua visão humanista, que integra todos os aspectos relativos ao ser humano, e dotado de intensa visão crítica, apresentou, com sua obra, Timor ao Ocidente, especialmente a Portugal, contribuindo de forma significativa para a ampliação do conhecimento acerca dessa então colônia tão distante e desconhecida.

No seu centenário, que se comemora neste ano de 2015, é de fundamental importância o resgate e divulgação deste poeta singular e de sua obra, que tanto contribuiu para a ampliação do conhecimento sobre o Timor Leste. 


\section{Referências}

BELO, Ruy. Apontamentos sobre o nomadismo em Ruy Cinatti. In: Obra poética de Ruy Belo. Org. e notas Joaquim Manuel Magalhães e Maria Jorge Pilar de Figueiredo. Lisboa: Editorial Presença, 1984.

BOFF, Leonardo. A águia e a galinha - uma metáfora da condição humana. Petrópolis: Editora Vozes, 2002.

BOFF, Leonardo. O despertar da águia - o dia-bólico e o sim-bólico na construção da realidade. Petrópolis: Editora Vozes, 2002.

BORGES, Maria João. Cinatti: a poesia como investidura. Revista Ler. Lisboa: Fundação Círculo de Leitores de Lisboa, 1997.

BORGES, Maria João. Em torno do conceito de "poesia pura": Cinatti, Sophia e Eugenio de Andrade. A poesia como investidura. Tese (Doutoramento em Literatura Portuguesa) - Faculdade de Letras da Universidade de Lisboa, 1996.

CAETANO, Marcello (Org.). Antologia colonial portuguesa. Lisboa: Divisão de Publicações e Biblioteca Agência Geral das Colónias, 1946.

CASTRO, Alberto Osório de. A ilha verde e vermelha de Timor. Lisboa: Edições Cotovia, 1996.

CINATTI, Ruy. Obra poética. Lisboa: Imprensa Nacional - Casa da Moeda, 1992.

CINATTI, Ruy. Um cancioneiro para Timor. Lisboa: Editorial Caminho, 1996.

CINATTI, Ruy. Archeologia ad usuum animae. Lisboa: Editorial Presença, 2000.

CINATTI, Ruy. Arquitectura timorense. Lisboa: Instituto de Investigação Científica Tropical, 1987.

CINATTI, Ruy. Corpo-alma. Lisboa: Editorial Presença, 1994.

CINATTI, Ruy. Esboço histórico do sândalo no Timor português. Lisboa: IICT, 1950.

CINATTI, Ruy. Explorações botânicas em Timor. Lisboa: IICT, 1950. 
CINATTI, Ruy. Impressões de uma viagem pelos territórios portugueses da África Ocidental. Lisboa: IICT, 1950.

RUBIO, Alfonso García. Unidade na pluralidade - o ser humano à luz da fé e da reflexão cristãs. São Paulo: Paulus, 2001.

SAID, Edward W. Orientalismo. O Oriente como invenção do Ocidente. São Paulo: Companhia das Letras, 1996.

STILWELL, Peter. A condição humana em Ruy Cinatti. Lisboa: Editorial Presença, 1995. 